\title{
Gambaran Pengetahuan Remaja Mengenai HIV/AIDS Setelah Mengikuti Program Hebat di Smp Negeri Kota Bandung
}

\author{
Ulfa Hidayah', Puspa Sari², Ari Indra Susanti² \\ ${ }^{1}$ Fakultas Kedokteran Universitas Padjadjaran \\ ${ }^{2}$ Departemen Ilmu Kesehatan Masyarakat, Fakultas Kedokteran Universitas Padjadjaran
}

\begin{abstract}
Abstrak
Kementerian Kesehatan Republik Indonesia (KEMENKES RI) sejak tahun 2005hingga tahun 2015 mencatat 68.917 kasus HIV/AIDS. Berdasarkan kelompok umur, presentase kasus tertinggi HIV/AIDS tahun 2015 terjadi pada remaja. Rendahnya pengetahuan remaja mengenai HIV/AIDS menyebabkan tingginya angka HIV/AIDS pada remaja. Upaya yang dilakukan untuk mencegah meningkatnya angka kejadian HIV/AIDS dengan meningkatkan pengetahuan remaja melalui program Hidup Sehat Bersama Sahabat (HEBAT). Tujuan penelitian ini adalah untuk mengetahui gambaran pengetahuan remaja mengenai HIV/AIDS setelah mengikuti program HEBAT di 4 SMP Negeri Kota Bandung. Penelitian ini dilaksanakan di SMP Negeri Kota Bandung pada tanggal 25 Juli sampai 3 Agustus 2016. Penelitian ini menggunakan metode deskriptif bersifat kuantitatif dengan pendekatan cross sectional. Pengumpulan data dilakukan dengan menggunakan kuesioner dan teknik cluster sampling serta stratified random sampling yang berjumlah 297 orang yang berasal dari empat sekolah dan menggunakan analisis univariat. Hasil Penelitian ini menunjukan bahwa 54,9 \% remaja mempunyai pengetahuan yang baik mengenai HIV/AIDS, 43,8 \% berpengetahuan cukup dan 1,3\% berpengetahuan kurang. Remaja perempuan memiliki pengetahuan yang lebih baik disbanding remaja laki-laki sebesar 57,8 $\%$, sedangkan laki-laki cenderung berpengetahuan cukup dibandingkan dengan perempuan sebesar $46,0 \%$. Sedangkan untuk remaja yang berpengetahuan buruk laki-laki cenderung lebih besar yaitu 2,0\% dibanding perempuan yang hanya $0,7 \%$. Simpulan dalam penelitian ini menunjukan bahwa pengetahuan pada remaja cenderung lebih baik setelah remaja mengikuti program HEBAT. Oleh karena itu dengan adanya program HEBAT diharapkan dapat menurunkan angka kejadian HIV/AIDS seiring dengan meningkatnya pengetahuan remaja.
\end{abstract}

Kata Kunci : HIV/AIDS, Pengetahuan, Program HEBAT

\section{Description of Adolescent Knowledge on HIV/AIDS After Attending Hebat Program in Public Junior High Schools in Bandung City}

\begin{abstract}
In 2005 until 2015, Ministryof Health of the Republic of Indonesia (KEMENKES RI) has recorded 68,917 HIV/AIDS cases. By the age group, the highest percentage of HIVIAIDS cases in 2015 occursin adolescents. Lack of knowledge on HIV/AIDS has led to the high rates of HIV/AIDS in adolescents. Efforts were carried out to prevent the increasing incidence of HIV/AIDS by improving adolescent knowledge with Hidup Sehat Bersama Sahabat (HEBAT) program. This study was aimed to describe adolescent knowledge on HIV/AIDS after attending HEBAT Program in Public Junior High Schoolsin Bandung City. This study was carried out from July 25 to August 3, 2016 in Public Junior High Schools. Method used in this quantitative study was descriptive with cross sectional approach. The data was collected using questionnaire to 297 adolescents from 4 schools obtained by cluster samplingand stratified random sampling techniques and was analyzed using univariat analysis. The result indicated that $54.9 \%$ of respondents have good knowledge, while $48.3 \%$ have adequate level of knowledge and $1.3 \%$ have poor knowledge. women have better knowledge than boys at 57.8\%, while men tend to be knowledgeable enough compared with women of $46.0 \%$. As for adolescents with bad knowledge of men tend to be larger that is $2.0 \%$ compared to women who only $0.7 \%$. Conclusion from this study is Adolecents have good knowledge after attending HEBAT programe.. Therefore, with this HEBAT program, it is expected to be able to decrease the incidence of HIV/AIDS by increasing adolescent knowledge.
\end{abstract}

Keywords : HIV/AIDS, Knowledge, HEBAT Program.

Korespondensi:

Ulfa Hidayah

Fakultas Kedokteran Universitas Padjadjaran

Jl. Raya Bandung-Sumedang KM 21 Jatinangor, Sumedang

Mobile : 089627879608

Email : Succespersson7@gmail.com 


\section{Pendahuluan}

Kementeriann Kesehatan (KEMENKES) sejak tahun 2005 sampai tahun 2015 mencatat 68.917 kasus HIV/AIDS. Berdasarkan kelompok umur, presentase kasus AIDS tahun 2015 didapatkan tertinggi pada remaja. Menurut hasil survei Dinas Kesehatan pada tahun 2012 Kota Bandung merupakan peringkat kedua setelah Kota Bekasi di Jawa Barat yang mempunyai jumlah penderita HIV/AIDS yang tinggi yaitu sekitar 379 orang menderita HIV dan 10 orang menderita AIDS. ${ }^{1}$ Salah satu penyebab masih tingginya angka HIV/ AIDS pada remaja adalah rendahnya pengetahuan remaja terkait HIV/AIDS. ${ }^{1}$

World Health Organization (WHO) mendefinisikan remaja adalah seseorang yang berusia antara 10-19 tahun. $^{2}$ Jumlah remaja di Indonesia menurut sensus penduduk tahun 2010 berjumlah 43.551 .815 jiwa, sedangkan tahun 2000 42.327.900 jiwa sehingga diperoleh nilai pertumbuhan 0,6 persen. Diproyeksikan jumlah remaja akan terus meningkat dengan pertumbuhan tetap. Jumlahnya akan terus mengalami peningkatan sampai tahun 2025 pada angka lebih dari 47 juta jiwa. ${ }^{3}$

Masa remaja merupakan masa yang penting dalam kehidupan seseorang. Masa remaja merupakan masa peralihan dari anak menjadi dewasa. Pada masa remaja sering kali muncul dorongan untuk mengetahui dan mencoba halhal baru dalam usahanya untuk mencari jati diri dan mencapai kematangan pribadi sesuai tugas perkembangannya. ${ }^{4}$

Rasa keingintahuan yang besar dan ketertarikan yang tinggi serta terjadi berbagai perubahan baik dari segi fisik maupun psikis akhirnya menyebabkan banyak masalah yang timbul pada kehidupan remaja. Pada akhirnya banyak masalah yang terjadi pada remaja, baik dari segi kesehatan, pendidikan, dan lain sebagainya. Salah satu masalah kesehatan remaja menurut hasil Survei Demografi dan Kesehatan Indonesia (SDKI) tentang Kesehatan Reproduksi Remaja (KRR) tahun 2012 menunjukan bahwa pengetahuan remaja tentang kesehatan reproduksi belum memadai yang dapat dilihat dengan hanya $35,3 \%$ remaja perempuan dan 31,2\% remaja laki-laki usia 15-19 tahun mengetahui bahwa perempuan dapat hamil dengan satu kali berhubungan seksual. ${ }^{4}$ Dampak kurangnya pengetahuan mengenai kesehatan reproduksi diungkapkan dalam penelitian yang dilakukan oleh Sahara tahun 2006 bahwa minimnya pengetahuan dan bimbingan kesehatan reproduksi pada remaja telah menyebabkan $72,9 \%$ kehamilan yang tidak diinginkan (KTD), $94,8 \%$ aborsi yang tidak aman, $5,2 \%$ aborsi di fasilitas atau tenaga kesehatan, $32,2 \%$ penyakit menular seksual (PMS), 54,3\% terinfeksi HIV/ AIDS. ${ }^{6}$

Jika ditinjau dari segi pendidikan, tingginya angka kejadian HIV/AIDS ini dapat dikurangi dengan suatu program yang dapat meningkatkan pengetahuan remaja mengenai HIV/AIDS. Salah satu upaya dunia pendidikan untuk meningkatkan pengetahuan remaja mengenai HIV/AIDS adalah membuat program Hidup Sehat Bersama Sahabat (HEBAT) yang dilakukan oleh Fakultas Kedokteran Universitas Padjadjaran yang bekerja sama dengan Dinas Pendidikan serta Dinas Kesehatan. Program ini bertujuan untuk meningkatkan pengetahuan remaja terutama mengenai HIV/AIDS dan mencegah siswa dari hal-hal yang menghalangi dirinya dalam menggapai cita-cita. ${ }^{9}$

Peningkatan pengetahuan pada remaja banyak memberikan dampak yang baik, diantaranya memperbaiki perilaku remaja. seperti yang diungkapkan pada penelitian Fitriany pada tahun 2013 menyebutkan bahwa adanya perbedaan sikap dan pengetahuan mengenai kesehatan reproduksi pada remaja yang sudah mengikuti program HEBAT dan belum pernah mengikuti program HEBAT. Pada siswa yang sudah mengikuti program HEBAT memiliki pengetahuan dan sikap yang lebih baik mengenai kesehatan reproduksi dibandingkan remaja yang belum mengikuti program HEBAT. ${ }^{10}$ Tujuan penelitian ini adalah untuk mengetahui gambaran pengetahuan remaja mengenai HIV/AIDS setelah mengikuti program HEBAT di SMP Negeri Kota Bandung dan untuk mengetahui gambaran pengetahuan remaja lakilaki dan perempuan mengenai HIV/AIDS setelah mengikuti program HEBAT di SMP Negeri Kota Bandung.

Berdasarkan berbagai data di atas, maka penulis tertarik untuk melakukan penelitian terkait hal tersebut mengenai "Evaluasi Pengetahuan Remaja Mengenai HIV/AIDS setelah mengikuti program HEBAT di SMP Negeri Kota Bandung".

\section{Metode}

Penelitian ini menggunakan metode deskriptif yang bersifat kuantitatif dan dilakukan dengan pendekatan cross sectional. Pada penelitian ini pengumpulan data hanya dilakukan pada satu waktu selama penelitian. Penelitian ini dilaksanakan pada tanggal 25 Juli sampai 3 Agustus 2016. Populasi penelitian ini adalah 1031 siswa dari SMPN 8 Bandung, SMPN 10 Bandung, SMPN 19 Bandung, SMPN 40 Bandung, setelah mengikuti program HEBAT di SMP Negeri Kota Bandung. Subjek pada penelitian ini adalah 
remaja kelas IX di empat SMP Negeri Kota Bandung. Sampel pada penelitian ini adalah remaja kelas IX sebanyak 240 orang yang terdiri dari empat SMP Negeri kota Bandung.

Pengambilan sampel pada penelitian ini menggunakan teknik cluster sampling dan stratified random sampling. Sebelum menentukan sampel minimum, tentukan terlebih dahulu jumlah populasi menggunakan teknik Cluster random sampling dengan membagi seluruh populasi menjadi wilayah tertentu. Setelah menentukan subjek penelitian selanjutnya adalah menetukan sampel minimum dengan menggunakan teknik stratified random sampling. Pada penelitian ini sampel minimum ditentukan dari seluruh subjek yang berjumlah 1301 orang. Seribu tiga ratus satu orang tersebut akan diambil beberapa orang untuk dijadikan sampel. Jumlah sampel yang ditentukan berasal dari rumus yang sudah ditentukan. Kriteria inklusi pada penelitian ini adalah remaja SMP kelas IX yang mengikuti program HEBAT dan yang bersedia untuk dijadikan responden. Sedangkan kriteria eksklusi pada penelitian ini adalah remaja SMP kelas IX yang tidak masuk sekolah pada saat pengambilan data dan remaja SMP kelas IX yang sedang mengikuti ujian/ulangan. Analisis data pada penelitian ini menggunakan analisis univariat.

Penelitian ini telah mendapatkan persetujuan dari Komite Etik Penelitian Kesehatan Universitas Padjajaran Fakultas Kedokteran.

\section{Hasil}

Tabel 1 Distribusi frekuensi pengetahuan remaja mengenai HIV/AIDS

\begin{tabular}{lcc}
\hline $\begin{array}{c}\text { Pengetahuan } \\
\text { HIV/AIDS }\end{array}$ & $\begin{array}{c}\text { Jumlah } \\
\text { (n) }\end{array}$ & $\begin{array}{c}\text { Total } \\
(\%)\end{array}$ \\
\hline Baik & 163 & 54,9 \\
Cukup & 130 & 43,8 \\
Kurang & 4 & 1,3 \\
Total & 297 & 100 \\
\hline
\end{tabular}

Tabel 2 Distribusi frekuensi pengetahuan remaja menurut jenis kelamin mengenai HIV/ AIDS

\begin{tabular}{lcccc}
\hline $\begin{array}{c}\text { Pengetahuan } \\
\text { HIV/AIDS }\end{array}$ & \multicolumn{2}{c}{ Laki- laki } & \multicolumn{2}{c}{ Perempuan } \\
(n) & (\%) & (n) & (\%) \\
\hline Baik & 78 & 52,0 & 85 & 57,8 \\
Cukup & 69 & 46,0 & 61 & 41,5 \\
Kurang & 3 & 2,0 & 1 & 0,7 \\
Total & 150 & 100 & 147 & 100 \\
\hline
\end{tabular}

Berdasarkan tabel 1. dapat dilihat bahwa sebagian besar responden mempunyai pengetahuan yang baik mengenai HIV/AIDS yaitu sebesar 54,9\%. Berdasarkan tabel 2. dapat dilihat bahwa remaja yang mempunyai pengetahuan yang baik adalah perempuan dibandingkan laki-laki sebesar $57,8 \%$. Sedangkan pengetahuan remaja yang cukup lebih tinggi pada laki-laki sebesar $41,5 \%$. Remaja yang berpengetahuan kurang masih ada sebesar 2,0\% pada remaja laki-laki dan $0,7 \%$ pada perempuan.

\section{Pembahasan}

Berdasarkan tabel 1. menunjukan bahwa remaja memiliki pengetahuan baik sebesar 54,8\%. Pengetahuan merupakan hasil dari tahu, dan ini terjadi setelah orang melakukan pengindraan terhadap suatu objek tertentu. Terjadi melalui panca indra manusia, yakni indra penglihatan, pendengaran, penciuman, rasa, dan raba. Sebagian besar pengetahuan manusia diperoleh melalui mata dan telinga. ${ }^{10}$

Pada dasarnya jika seseorang diberikan pendidikan kesehatan atau penyuluhan atau pengajaran sebelumnya maka pengetahuan seseorang akan menjadi lebih baik. Hal tersebut diungkapkan pada penelitian Anisa tahun 2015 bahwa terdapat pengaruh pendidikan kesehatan melalui penyuluhan terhadap pengetahuan dalam pencegahan HIV/AIDS pada remaja. ${ }^{11}$ Hal yang sama juga diungkapkan pada penelitian yang dilakukan oleh Yanti dkk tahun 2015 terdapat perbedaan rata-rata pengetahuan kesehatan reproduksi pada siswa/siswi SMPN 4 setelah diberikan pendidikan kespro dengan metode mentoring. ${ }^{13}$ Selain itu penelitian yang dilakukan oleh Sri dkk tahun 2016 juga mengungkapkan hal yang hampir sama bahwa adanya perbaikan pengetahuan setelah dilakukan penyuluhan menggunakan aplikasi mobile android sebesar $17,48 \% .{ }^{14}$ Hal tersebut juga diungkapkan dalam penelitian yang dilakukan oleh Imam tahun 2011 bahwa dengan adanya media yang memfasilitasi remaja diharapkan para remaja dapat terfasilitasi kebutuhan belajar dan memperbaiki pengetahuannya terutama mengenai HIV/AIDS..$^{15}$

Selain itu dalam penelitian Fitriani tahun 2013 dikatakan bahwa adanya perbedaan pola pikir remaja setelah mengikuti program HEBAT. ${ }^{10}$ Dari beberapa penelitian di atas dapat dilihat bahwa dengan adanya pemberian penyuluhan atau pengajaran sebelumnya kepada seseorang akan dapat memperbaiki pengetahuan seseorang.

Pada Tabel 2. menunjukan bahwa tingkat pengetahuan remaja pada kategori baik cenderung lebih tinggi pada perempuan dibandingkan remaja laki-laki sebesar $57,8 \%$. Sedangkan 
pengetahuan remaja yang cukup lebih tinggi pada laki-laki sebesar $46,0 \%$. Remaja yang berpengetahuan kurang masih ada sebesar $2,0 \%$ pada remaja laki-laki dan $0,7 \%$ pada perempuan. Sedangkan pengetahuan remaja pada kategori cukup didominasi oleh remaja laki-laki

Pada penelitian yang dilakukan oleh Anisa tahun 2015 bahwa pengetahuan remaja perempuan $57,5 \%$ lebih unggul dibandingkan remaja lakilaki yang hanya $20 \%{ }^{11}$ Hal yang sama juga diungkapkan dalam penelitian yang dilakukan oleh Gusti tahun 2015 bahwa pengetahuan remaja perempuan lebih besar $52,5 \%$ dibandingkan remaja laki-laki yang hanya $47,5 \%{ }^{16}$

Hal yang berbeda diungkapkan oleh Survey Demografi Kesehatan Indonesia (SDKI) pada tahun 2012 bahwa terdapat perbedaan tingkat pengetahuan remaja mengenai HIV/AIDS pada laki-laki lebih baik dari pada perempuan, pengetahuan remaja laki-laki mengenai HIV/ AIDS secara komprehensif sebesar $10,6 \%$ dan perempuan sebesar $10 \% .^{17}$

Simpulan pada penelitian ini berdasarkan dari hasil analisis dan pembahasan yang sudah dilakukan bahwa remaja yang mempunyai pengetahuaan yang baik mengenai HIV/AIDS sebesar 54,9\%, pengetahuan cukup 43,8\% dan pengetahuan kurang sebesar 1,3\%. Hasil analisis data menunjukan bahwa pengetahuan pada remaja cenderung lebih baik setelah remaja mengikuti program HEBAT. Hal tersebut didukung dengan beberapa hasil penelitian yang dilakukan sebelumnya yang dibahas pada pembahasan bahwa ketika seseorang melalui sebuah proses melihat, mendengar dan mengamati maka kemungkinan pengetahuannya akan bertambah walaupun dengan menggunakan metode yang berbeda beda.

Saran untuk penelitian ini adalah sebaiknya dilakukan penelitian kembali dengan jumlah sekolah dan variabel yang lebih beragam. Peneliti juga berharap pemerintah Kota Bandung dapat mengembangkan program HEBAT serta menjadikan program ini sebagai salah satu muatan lokal di seluruh SMP di Kota Bandung.

Keterbatasan penelitian ini adalah waktu, waktu merupakan salah satu keterbatasan penelitian yang dialami oleh peneliti sehingga hasil penelitian yang telah dilakukan kurang mewakili judul yang ditentukan oleh peneliti. Selain itu jumlah Sekolah yang diteliti juga menjadi keterbatasan peneliti, jumlah sekolah yang diteliti harusnya lebih banyak dibandingkan pada penelitian ini. Mengingat terbatasnya waktu dan juga biaya yang ada sehingga peneliti hanya menggunakan beberapa sekolah di Kota Bandung untuk mewakili sekolah lainnya.

\section{Daftar Pustaka}

1. Pusat Data dan Informasi Sekertariat Jendral Kementrian Kesehatan Indonesia Data dan Informasi tahun 2012. Resume Profil Kesehatan di Provinsi Jawa Barat ; Kementrian kesehatan Republik Indonesia. 2012; 14

2. Badan Kependudukan dan Keluarga Berencana Nasional. Ayo menjadi remaja berkarakter : religius, sehat, cerdas, produktif. Kependudukan DKP Jakarta: BKKBN; 2013.

3. Yulifah, Yuswanto. Asuhan Kebidanan Komunitas. Jakarta: Salemba Medika; 2012.

4. Pusat Data dan Informasi Sekertariat Jendral Kementrian Kesehatan Indonesia. Situasi kesehatan reproduksi remaja; Kementrian kesehatan RI 2015.

5. Sahara dkk. Pengaruh Pengetahuan remaja terhadap perilaku seksual remaja; Jakarta. 2006.

6. Hinduan $\mathrm{Z}$ et al. Buku HEBAT : bacaan siswa Pendidikan kesehatan reproduksi. Bandung; 2011.

7. Jauhari F. Perbedaan intensi ber perilaku seksual pranikah antara siswa berpacaran yang mengikuti program HEBAT dengan yang tidak mengikuti program HEBAT di Kota Bandung. Fakultas Psikologi Unpad. Bandung; 2013.

8. Notoatmodjo S. Promosi kesehatan dan perilaku kesehatan Jakarta: Rineka cipta; 2012.

9. Annisa. Pengaruh Penyuluhan Kesehatan tentang HIV/AIDS terhadap tingkat pengetahuan dalam pencegahan HIV/AIDS pada remaja. Sekolah Tinggi Ilmu Kesehatan Asiyah Yogyakarta. Yogyakarta; 2015.

10. Yanti dkk. Pengaruh pendidikan kesehatan reproduksi menggunakan metode mentoring terhadap pengetahuan remaja tentang kesehatan reproduksi. Keperawatan Soedirman. 2015;11.

11. Sri dkk. Peningkatan Pengetahuan HIV/ AIDS dengan memanfaatkan aplikasi mobile Android. Jakarta; $2016 ; 4$.

12. Hasan IF. pengembangan multimedia interaktif layanan bimbingan berbasis role playing game (RPG) tentang kesehatan reproduksi remaja untuk siswa SMP dan MTs.Jogjakarta; 2016.

13. Marsito dkk. Kontribusi Fungsi Keluarga terhadap pencegahan penularan HIV/ AIDS pada kalangan Remaja di desa sampang sempor Kab Kebumen. kesehatan keperawatan. Kebumen; 2016;12:4.

14. Gusti d. Intervensi penyuluhan kesehatan terhadap peningkatan pengetahuan dan sikap 
Ulfa Hidayah : Gambaran Pengetahuan Remaja Mengenai HIV/AIDS Setelah Mengikuti Program Hebat di Smp Negeri Kota Bandung

remaja tentang HIV/AIDS di SMA 1 Sidemen Kabupaten karangasem, provinsi Bali. 2015.

15. Badan Kependudukan dan Keluarga

Berencana Nasional. Informasi kesehatan reproduksi bagi remaja. In: Edukasi Direktorat Advokasi dan Komunikasi Informasi Edukasi editor. Jakarta.2010. 